\title{
The Role of Geography, Demographics, Bandwidth Speed and Internet Availability in Rural West Virginia Communities: A Multiple Case Study of the 2012 Cards of Hope Fundraiser
}

\author{
Rebecca Diehm \\ West Virginia University
}

Follow this and additional works at: https://researchrepository.wvu.edu/etd

\author{
Recommended Citation \\ Diehm, Rebecca, "The Role of Geography, Demographics, Bandwidth Speed and Internet Availability in \\ Rural West Virginia Communities: A Multiple Case Study of the 2012 Cards of Hope Fundraiser" (2013). \\ Graduate Theses, Dissertations, and Problem Reports. 441. \\ https://researchrepository.wvu.edu/etd/441
}

This Thesis is protected by copyright and/or related rights. It has been brought to you by the The Research Repository @ WVU with permission from the rights-holder(s). You are free to use this Thesis in any way that is permitted by the copyright and related rights legislation that applies to your use. For other uses you must obtain permission from the rights-holder(s) directly, unless additional rights are indicated by a Creative Commons license in the record and/ or on the work itself. This Thesis has been accepted for inclusion in WVU Graduate Theses, Dissertations, and Problem Reports collection by an authorized administrator of The Research Repository @ WVU. For more information, please contact researchrepository@mail.wvu.edu. 
The Role of Geography, Demographics, Bandwidth Speed and Internet Availability in Rural West Virginia Communities:

A Multiple Case Study of the 2012 Cards of Hope Fundraiser

\section{Rebecca Diehm}

Thesis submitted to the

P.I. Reed School of Journalism at West Virginia University

in partial fulfillment of the requirements

for the degree of

Master of Science

in

Journalism

Steve Urbanski, Ph.D., Chair

Kelley Crowley, Ph.D.

Elizabeth Oppe, Ph.D.

Phil Caskey, M.S., M.A.

School of Journalism

Morgantown, West Virginia

2013

Keywords: public relations, bandwidth, Internet, fundraising, etc. 


\begin{abstract}
The Role of Geography, Demographics, Bandwidth Speed and Internet Availability in Rural West Virginia Communities:

A Multiple Case Study of the 2012 Cards of Hope Fundraiser
\end{abstract}

Rebecca Diehm

Today, social media has become a popular public relations tool in the promotion of campaigns and fundraisers. While this new addition may be a key tool in the promotion of certain fundraisers and campaigns, this study was designed to focus on what public relations methods successfully promote events, campaigns and fundraisers in rural areas, such as those in West Virginia. The objective of this master's thesis is to support the notion that press releases are still the foundation of public relations methods not only in West Virginia, but in rural communities throughout the United States. In order to support this notion, data was collected and analyzed on the effect of four variables in the promotion of the 2012 Cards of Hope fundraiser. The findings of this study suggest that in rural areas, it is important to analyze the targeted audience and use traditional public relations methods to successfully promote a fundraiser. 


\section{Acknowledgements}

When beginning graduate school, I never would have thought that my thesis research process could make such a positive impact on my life. The knowledge I have gained throughout my experiences and research is incomparable. I would not have reached this point without the help and support of many important people in my life.

I would like to thank my chair Dr. Steve Urbanski for his constant support and helpful advice throughout both my undergraduate and graduate careers. You have been there every step of the way for the past four years. I feel privileged to have met and worked with someone as knowledgeable, passionate and kind as you. I would not have been able to accomplish what I have without your guidance and support.

I have also been fortunate enough to have three amazing committee members work with me throughout this process. Dr. Elizabeth Oppe, Dr. Kelley Crowley and Phil Caskey.

Dr. Oppe has been incredibly helpful and supportive before, during and after my thesis research process. After deciding to change my methodology, you were the one who helped me decide what my next steps were. Your undivided attention and constant words of encouragement gave me the confidence I needed to get where I am today and for that I am grateful.

I had the privilege of having Dr. Crowley as a professor in one of my undergraduate public relations classes. You were the one who reaffirmed my love for public relations. I remember calling you panicked because I was unsure of my methodology and after only a few short minutes we decided I should do a case study. The impact you had on me during my undergraduate career made me positive I wanted you to be on my committee. You are an amazing person inside and out and I am thankful for all of your help.

During my second year of graduate school I took a class with Phil Caskey. His passion for public relations and knowledge on the subject amazed me. After our first class, I was certain I wanted you to be on my committee. That was one of the best decisions I have ever made. You have been incredibly helpful and supportive throughout this entire process. Thank you for everything.

I would like to thank my amazing family because without them I would have never gotten here. You have always believed in me, even when I didn't. You're unconditional love and support has gotten me to where I am today.

Finally, I would like to thank all of my friends but especially Katie Barker and Janelle Schneider. You have been there through the ups and downs and I am lucky to have you in my life. Thank you for always being there. 


\section{Table of Contents}

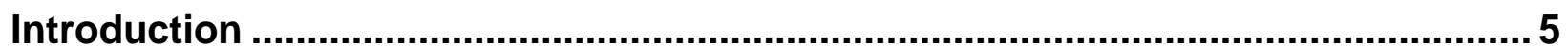

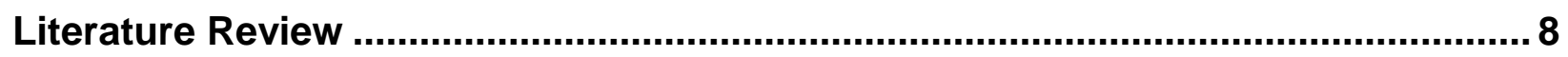

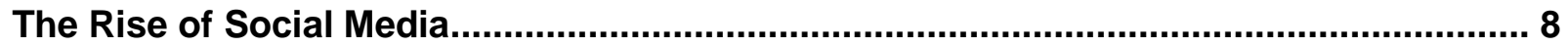

Social Media PR - Inexpensive, Fast and Reaches Millions ........................................... 9

Traditional public relations methods - Safe, Reliable and Accurate ..............................12

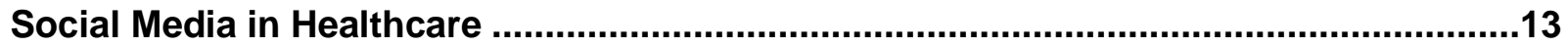

Word-of-Mouth Communication ...............................................................................15

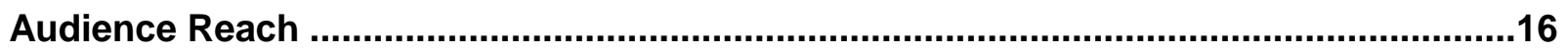

Research Questions and Hypotheses ..................................................................... 17

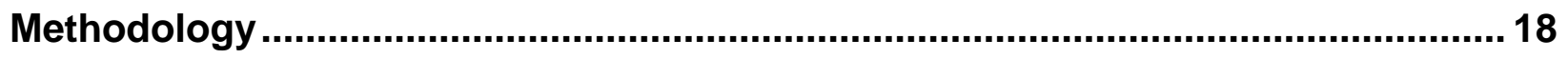

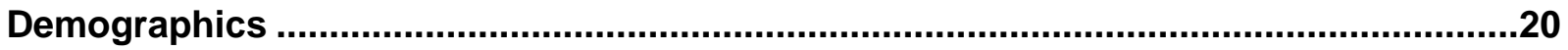

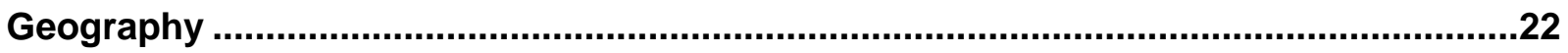

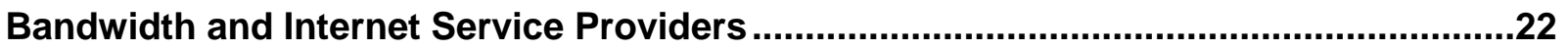

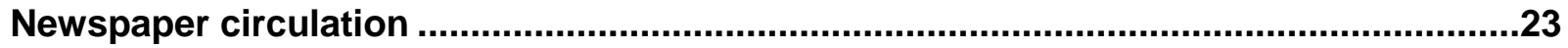

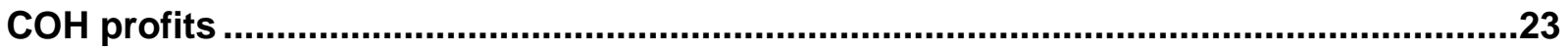

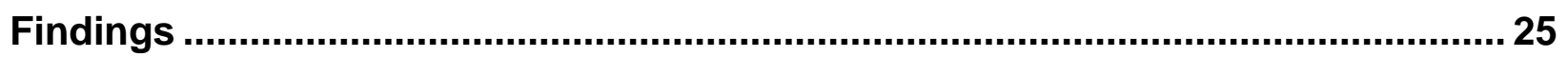

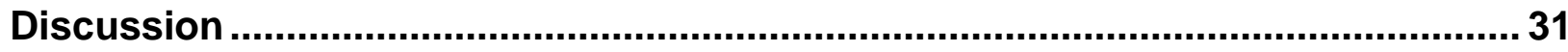

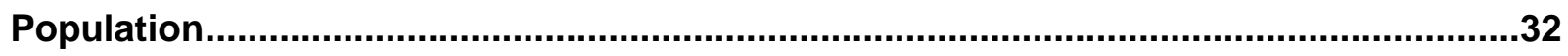

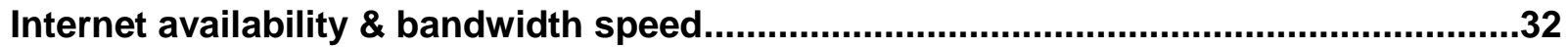

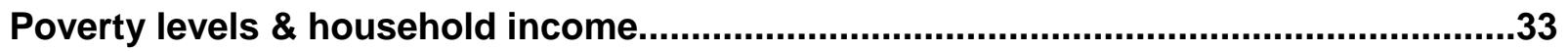

Newspaper subscriptions vs. Internet packages .........................................................34

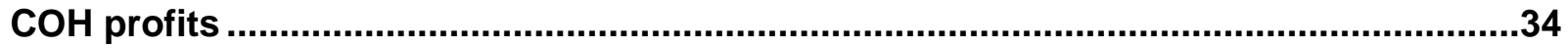

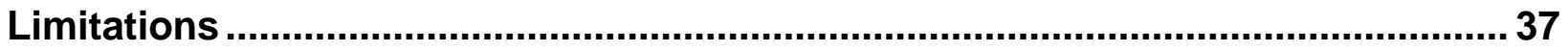

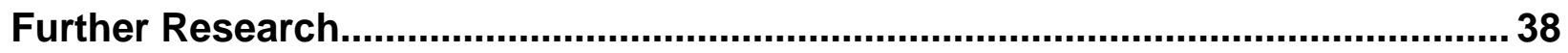

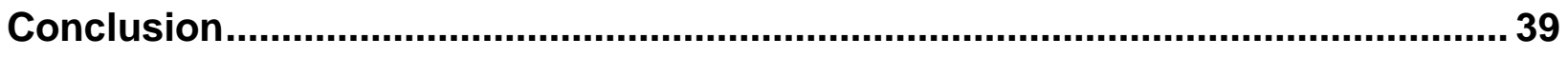

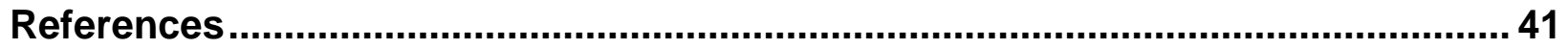




\section{Introduction}

Newspapers are seen being read by the man on the metro on his way to work, by the woman at the breakfast table and by the college student before class starts. Social media forms are also seen being used on the phone of the man on the metro, by the woman at the breakfast table and by the college student waiting for class to begin. For public relations practitioners, the question arises, what's the best way to communicate to the targeted public? Which is better, new media or traditional public relations methods?

Recent literature is claiming that new media forms such as Facebook and Twitter, are the main way to reach consumers. "Today, the Internet implementation in the marketing process is inexpensive, delivers instant international reach, offers great real time feedback, and reaches millions of people for whom the web is the center of virtually all communications" (Melanthiou \& Papasolomou, 2012, p. 319). Recent literature share the same view as Melanthiou and Papasololmou, that social media is growing and reaches a wide range of people. This viewpoint is not incorrect, but limited. There has been a lack in literature focusing on what public relations methods are best when targeting an audience in a rural area. In order to address this question, a case study was conducted. This study focused on the effect four variables had on the promotion of the 2012 Cards of Hope $(\mathrm{COH})$ fundraiser.

$\mathrm{COH}$ are greeting cards designed by West Virginia University Children's Hospital cancer patients, survivors, and their siblings. Ten artist's cards are chosen and then sold to the general public. In 2012, the fundraiser finished its $21^{\text {st }}$ year. The cards are the main resource for the WVU Cure Kids Cancer Fund. The fund ensures that patients 
and their families receive state-of-the-art medical care, as well as psychological and social support.

The Pediatric Cancer Care and Research Fund was created in 1991. Later the name was changed to Cure Kids Cancer Fund. The fund's mission is to raise money that will benefit patients in the pediatric hematology and oncology program. A committee reviews all requests for funds. The money advances the pediatric hematology and oncology team's mission by providing state-of-the-art research and support services that enhance the quality of life for patients and their families during treatment and after. The funds are used for special events such as holiday parties, camps, activities/crafts, educations and resource materials, or services to support the care of patients while they are in a clinic or during hospitalization, such as drinks for patients in clinic and new patient handbooks.

Each year, the Planning, Marketing and Communications department in the WVU Health Sciences Center writes an individual press release featuring each greeting card artist. The press releases are sent to the newspaper choice of the artist and a separate press release featuring all of the artists is sent out statewide. The 10 artists chosen in the 2012 fundraiser are from towns in West Virginia, Maryland and Ohio. In order to support the notion that press releases are the foundation of public relations methods in rural areas, specifically those in West Virginia, five artist's hometowns were selected for this multiple case study.

This multiple case study will analyze the effect four variables: demographics, geography, bandwidth speed and Internet availability had on the promotion of the 2012 
$\mathrm{COH}$ fundraiser. Throughout the study, various reliable sources such as the United States Census Bureau, the 2012 Editor \& Publisher Yearbook and Internet Service Provider representatives were referred to and through those sources observations were made in order to support the claim that traditional public relations methods, such as press releases, still have a place in rural communities of not only West Virginia, but also in rural communities throughout the United States. 


\section{Literature Review}

\section{The Rise of Social Media}

Social media has become an intricate part of our lives. In the world of mass communication, it has become a powerful form of new communication. Social media is empowering people to become the new influencers, and it is forcing public relations and marketing professionals to recognize and include these powerful tools in their advertising and marketing communications strategies (Solis \& Breakenridge, 2009). It has forced professionals and consumers to become familiar with the new phenomenon. The use of social media in public relations has created a new way to reach a targeted audience. When referring to fundraising and campaigns, social media forms are used in order to promote the fundraiser or campaign. Social media has the ability to reach a wide range of people. This new form of media has a direct effect on how public relations practitioners reach their targeted audience. According to Ullah, (2012):

The modern era of internet has widened the field of fundraising studies and provides an attractive way to reach more donors effectively in less and competitive time through an organization's web site and email, while Social Networking has widened the theory in a more effective way in order to reach more people through Word of Mouth (p. 74).

This form of new media has become the norm for sending and retrieving news into the world. In only a decade, the role of technology in public relations has grown tremendously; few professionals would argue against the use of electronic media in public relations activities (Kent \& Taylor, 2009). Sending a tweet, writing a Facebook post, and/or blog submitting entry is all a way of life now. This new form of media is 
essentially a public relations practitioners dream. It has grown and is now the new form of communication.

The communication from consumer to consumer has increased through social media, but the communication between a business and consumer has risen to a new level. The different ways of communicating through social media allows consumers to connect on a deeper level and become more involved. "Although traditional media (such as radio, TV, newspapers and magazines) remain common communication tools, social media are gaining in population and have the potential to change the way in which practitioners communicate" (Bridgen, 2011, p. 62). The reach of social media has no limits, and allows a better, faster and less expensive way to communicate with others. This phenomenon is pressuring the public relations world to promote through social media.

It is estimated that by 2015 , the number of people and businesses who have social networking accounts will reach over three billion (Neiger et al., 2012). Promoting through social media is rising to the top in the public relations world, and it is important that it is targeting an audience in the best form possible.

\section{Social Media PR - Inexpensive, Fast and Reaches Millions}

According to Melanthiou \& Papasolomou (2012):

Today, the Internet implementation in the marketing process is inexpensive, delivers instant international reach, offers great real time feedback, and reaches millions of people for whom the web is the center of virtually all communications (p. 319). 
While traditional public relations tactics are familiar and trustworthy, social media has become a useful addition in the public relations realm. The rise of social media as a primary tool for communication, the mediating role played by traditional media between companies and publics has diminished (Khang, Ki, \& Ye, 2012). It allows people to express opinions and transmit news freely. Companies and individuals are leaning on social media tactics to communicate with the public. Due to this rise of social media, traditional public relations methods are depreciating. The immediate result of using social media is an attractive feature to those in public relations. The ability to reach your audience through a click of a button with no expenses and provides feedback and responses quickly is a public relation's practitioner's dream. Curtis et al. (2010) state, as social media grows, it is essential for public relations practitioners to recognize the resourcefulness of these tools and take advantage of every available opportunity to effectively reach their publics.

Social media allows the practitioner to connect directly with the consumer. This relationship has the ability to grow and become stronger, therefore, creating a strong bond between the two. The consumer may then either "Like" the business on Facebook or follow them on Twitter. Creating this relationship and interacting through these social media outlets increases the awareness of the event, organization or the product being publicized. The development of individual and client relationships does more than simply benefit the team; seen through the prism of emotional labor, the employee is using their personality, interests and character to benefit a wide range of people, which will include their employers, the client and themselves (Bridgen, 2011). 
The power and control given to consumers through social media has created appealing new ways to communicate freely. Users are now able to spread news and their opinions through a click of a button. Key audiences have instant access to content broadcasted through social media forms whether it is "news" that happened today or ten years ago, the value of information has increased dramatically (Miller, 2012). Through Facebook and Twitter, users are able to share and retweet messages, therefore, reaching millions more people. "User-generated content has flipped traditional PR on its head, leaving many communications professionals and journalists dazed and confused" (Solis \& Breakenridge, 2009, p. 1).

Professionals and journalists must come to terms that this new form of communication is growing and it has positive aspects that may be priceless for businesses and organizations. The Public Relations Education Commission Report said, "Often, new technological forms and channels, such as electronic pitching, Podcasting, and blogging, prevail over traditional news releases and media kits (Kent \& Taylor, 2009, p. 209). Social media puts consumers in charge of how news is spread. This new form of media gives consumers the freedom voice their opinion all around the world. Consumers choose which forms of social media they want to use, what they want to know about and what they want to share with others.

Users "Like" certain businesses and organizations. They are in control of where they get their information. Bridgen (2011) says,

What differentiates social media channels (for instance, blogs, micro blogging sites such as Twitter, social networking sites) from established media types is that they enable the sharing of information on topics relating to an interest of 
theme among audiences who are niche, global or both and across traditional demarcations (p.62).

The numerous forms of social media have opened up many doors for the public relations practitioner and are beneficial for the user, business and/or organization. "Social media offers numerous opportunities for public relations practitioners to interact with the public while adopting new forms of technology and integrating them into their everyday lives" (Curtis et al., 2010, p. 90).

\section{Traditional public relations methods - Safe, Reliable and Accurate}

While social media forms are rising and becoming a part of practitioner's promotional methods, traditional public relations methods are still useful and effective. People are saying that press releases are dead, but that is not true for direct-toconsumer news releases (Scott, 2007). Public relations is about connecting with the targeted audience. Researching and analyzing the targeted audience decides how that audience will be reached. Communicating through social media is only useful if the targeted audience partakes in those forms of social media. "While public relations pros need to stay ahead of the trends and target their audiences on multiple platforms, it is important not to throw away some of the traditional tactics to the wayside" (Fathi, 2012, para. 1). Traditional methods are still necessary in public relations and a balance between traditional and new methods may lead to a successful fundraiser or campaign. When the actual effectiveness of social media is scrutinized and their use in public relations held up for critique, little evidence exists that social media is an effective tool for relationship building between organizations and publics (Kent \& Taylor, 2009). 
"Lariscy, Avery, Sweetse, and Howes (2009) surveyed journalists and found that social media were rarely selected by journalists as a first choice for gathering news" (Kent \& Taylor, 2010, p. 210). Journalists still turn to other forms of news before using social media. Traditional public relations methods such as press releases are still are a huge part of delivering news to different targeted audiences. Public relations practitioners who are turning to social media need to remember that promoting through social media is completely different from promoting through traditional public relations methods. As Bridgen (2011) stated:

Practitioners also need to understand, and follow, online conventions that may be radically different from that used by traditional media and sometimes without understanding or knowing the identity, motivations or characters of the people with whom they are dealing (p.62).

There are situations where traditional public relations methods are more appropriate and effective and situations where forms of social media are more successful. It depends on the audience being targeted. Researching and deciding the best way to connect with the targeted audience is the key to a successful public relations plan. Today, the communications industry needs to connect with customers directly while still using traditional and new media influencers to also reach them (Solis \& Breakenridge, 2009).

\section{Social Media in Healthcare}

In healthcare public relations and communication, there are many rules when it comes to social media. For this reason, "At the organizational level, many businesses and healthcare institutions have not yet adapted to the ongoing shift toward public social communication and the accompanying legal and ethical issues" (Cain, 2011, p. 1036). 
Hospitals have been late to acquire this new form of public relations due to the legal and ethical issues that may arise from Facebook posts or tweets. According to Ullah (2012):

Due to the emergence of Internet and social media in recent years, the whole scenario of donation collection methodology has been changed but unfortunately there is very little data on the linkage of social media and fundraising strategy, this limitation is a challenge for us and needs an empirical assessment (p. 78).

There are numerous examples of health care professionals being disciplined for ill-advised social media posts containing private patient information (Cain, 2011). Social media has the potential to improve the way public health agencies engage, interact and communicate with its various audiences (Neiger et al., 2012). Social media can offer new ways to promote the institution if executed properly.

The audience that a healthcare institution is targeting may be better reached through traditional public relations methods or forms of social media. It is also possible that the combination of the two could result in increased awareness and promotion. Once again, researching the targeted audience and deciding which public relations method to use will yield the best results. Social media techniques will become more abundant as public relations practitioners become mindful of their effectiveness in regards to reaching target audiences, promoting a specific cause, and further developing communication strategies (Curtis et al., 2010).

The beauty of social media is the ability to easily share information with others. For example, concerning the Cards of Hope fundraiser, it is possible for someone to share the Facebook post about an artist's card and then have the post reach a new audience. Today, people are able to retrieve and analyze information about people and 
organizations instantly with a desire to share the information with others (Melanthiou \& Papasolomou, 2012).

\section{Word-of-Mouth Communication}

Word-of-mouth (WOM) communication can be done through both traditional public relations and forms of social media. The targeted audience can be reached through the press releases that are then published by newspapers. The targeted audience also can be reached through forms of social media. Through either of the two methods, the subscribers are then the way information gets spread. "Consumergenerated media encompasses all the marketing messages and brand exchanges created by consumers themselves which subsequently result in creating word-of-mouth communication and a buzz about the brand" (Melanthiou \& Papasolomou, 2012, p. 320). WOM is a useful way to spread information about a promoted event. All that is needed is one person to spread the news then the information is out there for everyone to share. "WOM strategy is a key area because many consumers in various sectors rely on the product experiences and advice of the competent people." (Argan, 2012, p. 216). Consumers of new media forms spread information to friends and family Consumers that communicate and spread news with friends and family increases

Marketers are realizing that social media gives the power to consumers to move from spreading the word about brands from a one-to-one basis to a one-to-hundreds, or even one-to-thousands (Melanthiou \& Papasolomou, 2012). Some believe that word of mouth is even stronger in the online world (Melanthiou \& Papasolomou, 2012).

Marketing public relations has the ability to work effectively with traditional promotional methods to help generate an immediate response, create long-term 
relationships and spread WOM (Melanthiou \& Papasolomou, 2012). In a town where the population is less than 1,000 , word-of-mouth communication and traditional public relations methods may be the only way news is received.

\section{Audience Reach}

The geography and demographics of the targeted audience raise the question of how they will be reached. In rural communities, press releases may be the best way to spread the news. In heavily populated urban communities, using forms of social media may be the most practical way to spread the news. Social media use differs between rural and urban states (Neiger et al., 2012). It is important to know your audience.

As stated earlier, determining the best way to contact and connect with the target audience will bring back the best results. Consumers living in urban areas are more likely to use social media forms than those living in rural areas. Different variables decide whether a consumer is able to use social media forms. "Compared to other adults, mobile local news consumers skew younger, live in higher-income households and live in non-rural areas" (Bulldog Reporter, 2012). Research has found that on any given day, "...people living in rural communities are less likely than urban residents to visit a video sharing site and only $9 \%$ of Twitter users live in rural communities" (Neiger et al., 2012, p. 5). Demographics and geography are key variables to research and analyze before conducting a fundraiser. 


\section{Research Questions and Hypotheses}

As the literature has shown, there has been a lack of research done on the topic of public relations use in rural communities. Much research and analysis has gone into defending the positive effects social media has when paired with public relations. Yet there has been little research into the effects a press release has in rural communities in the case of this research. To fill this gap, the following hypotheses and research questions have been proposed:

RQ1: How do demographics in the five communities chosen help determine how the residents receive their news?

RQ2: How does geography in the five communities chosen help determine how the residents receive their news?

RQ3: How does the bandwidth speed in the five communities chosen help determine how the residents receive their news?

RQ4: How does the lack of financial gain for Internet Service Providers help determine how the residents receive their news?

H1: The profits raised from this year's Cards of Hope fundraiser will be greater than the profits raised from the 2011 Cards of Hope fundraiser.

H2: Press releases are the foundation of public relations in rural communities, specifically West Virginia. 


\section{Methodology}

The objective of this study is to highlight the role press releases and traditional public relations methods have in rural communities. This objective will be reached through data collection and research of four variables: demographics, geography, bandwidth speed and Internet availability in the rural communities. In order to study social phenomena, an intensive approach must be taken. Such an approach focuses on only a handful of instances in order to study a phenomenon in depth. Each instance is studied in its own specific context, and in greater detail than in extensive research (Swanborn, 2010). A multiple case study enables the researcher to explore differences within and between cases. The goal is to replicate findings across cases. Because comparisons will be drawn, it is imperative that the cases are chosen carefully so that the researcher can predict similar results across cases, or predict contrasting results based on a theory (Yin, 2003). This study will be an explanatory case study, meaning it presents data bearing on cause-effect relationships, explaining which causes produced which effects (Yin, 1993). In this case, the research issue was how and why do the four variables effect the promotion of the Cards of Hope fundraiser?

This study will focus on the five hometowns of the Cards of Hope artists. The three out of the five are defined as being rural, while the other two are defined as UCs (See Figure 1). In order to focus on West Virginia communities specifically, these five communities were the only West Virginia hometowns of the 10 artists chosen for the fundraiser.

This study researched four variables: demographics, geography, bandwidth speed and lack of financial gain for Internet Service Providers. Focusing on the 
community's demographics determines whether the households in the communities have the financial ability to use the Internet. The population, households, income and poverty levels of each West Virginia community were analyzed.

The geography of each community decides if the house is in an area where Internet can be received. If the house is placed in an area where an Internet connection cannot be picked up, then the house cannot receive Internet regardless of bandwidth speed or demographic reasons.

The bandwidth speed of each community decides whether the household has the ability to use Internet in their home or on their mobile device. If the household can use the Internet then determining the speed of Internet determines whether it is financially sound to purchase Internet if the connection is low.

Analyzing the lack of financial gain for large cable and Internet providers gives reasoning to why many rural West Virginia communities are without Internet. If cable and Internet carriers feel that there is no financial gain in building a cell tower in that community, then that limits the availability of Internet in the community.

In order to show the data collection process, a table has been created to show how each research question was researched and analyzed (Figure 1). 
Figure 1: Research methodology

\begin{tabular}{|c|c|c|c|c|}
\hline Research Questions & Units of Analysis & Data Source & $\begin{array}{l}\text { Collection } \\
\text { Procedure }\end{array}$ & $\begin{array}{l}\text { Analysis } \\
\text { Procedure }\end{array}$ \\
\hline $\begin{array}{l}\text { How do demographics } \\
\text { in the five } \\
\text { communities chosen } \\
\text { help determine how } \\
\text { the residents receive } \\
\text { their news? }\end{array}$ & $\begin{array}{l}\text {-Population } \\
\text {-Households } \\
\text {-Income } \\
\text {-Poverty levels }\end{array}$ & $\begin{array}{l}\text { - United States } \\
\text { Census Bureau }\end{array}$ & Document review & Data analysis \\
\hline $\begin{array}{l}\text { How does geography } \\
\text { in the five } \\
\text { communities chosen } \\
\text { help determine how } \\
\text { the residents receive } \\
\text { their news? }\end{array}$ & $\begin{array}{l}\text { West Virginia high } \\
\text { speed Internet } \\
\text { ranking }\end{array}$ & $\begin{array}{c}\text {-Net Index by } \\
\text { Ookla }\end{array}$ & Document review & Data analysis \\
\hline $\begin{array}{l}\text { How does the } \\
\text { bandwidth in the five } \\
\text { communities chosen } \\
\text { help determine how } \\
\text { the residents receive } \\
\text { their news? }\end{array}$ & $\begin{array}{l}\text { Megabits per } \\
\text { second (Mpbs) }\end{array}$ & $\begin{array}{l}\text {-Comcast } \\
\text {-Frontier } \\
\text {-Verizon } \\
\text {-Citynet }\end{array}$ & $\begin{array}{l}\text { Document review } \\
\text { and phone call to } \\
\text { ISP representative }\end{array}$ & Data analysis \\
\hline $\begin{array}{l}\text { How does the lack of } \\
\text { financial gain for } \\
\text { Internet providers help } \\
\text { determine how the } \\
\text { residents receive their } \\
\text { news? }\end{array}$ & Internet availability & $\begin{array}{l}\text {-Comcast } \\
\text {-Frontier } \\
\text {-Verizon } \\
\text {-Citynet }\end{array}$ & $\begin{array}{l}\text { Document review } \\
\text { and phone call to } \\
\text { ISP representative }\end{array}$ & Data analysis \\
\hline
\end{tabular}

\section{Demographics}

The United States Census Bureau was analyzed in order to collect reliable demographic information about the five West Virginia hometowns. Each hometown's population, number of households, average income and poverty level were researched. Each of these sections are important to collect percentages and number from because they provide support to the notion that traditional public relations methods, such as 
press releases, still have a place in rural communities of not only West Virginia, but also in rural communities throughout the United States.

The population of each hometown was collected in order to show whether the town is defined as rural or Urban Clusters (UCs) according to the U.S. Census Bureau. In order to show the age that populates each town the most, persons under 5, persons under 18 and persons 65 and older percentages were collected. This data is important to include in this study because certain age groups may not use the varied forms of social media even if they are available in their home. Collecting this data decides whether the majority of people each hometown are at an age where social media would be utilized.

The average amount of households in each hometown were included in the data collection because the number of households gives an idea how many households would need to be provided with the Internet in order to use forms of social media. The number of persons per household was collected to show how many people in the household would need to use the Internet if it was available. It was important to collect the per capita money and household income for each hometown. By collecting these numbers, it shows whether purchasing an Internet package from and Internet Service Provider (ISP) was financially sound. This is why the poverty level percentages were also collected. The poverty level may provide support to the notion that certain communities may not have the financial ability to purchase Internet packages for their home. 


\section{Geography}

In order to support the notion that traditional public relations methods are still the foundation of public relations in rural communities, high-speed Internet data was collected. This data was collected from Ookla's Net Index and is shown in graph form on Google's Public Data webpage. This data is relevant to this study because it shows the download speed rankings of all 50 states. Determining West Virginia's rank provides support to the idea that mostly rural states do not have the Internet availability as other states in urban areas do. Therefore, if Internet cannot be easily attained, then rural area residents receive their news through other forms, such as newspapers.

\section{Bandwidth and Internet Service Providers}

For this study, it is important to analyze the bandwidth speed available to residents in West Virginia, as well as the Internet availability in all five hometowns. In order to collect reliable bandwidth speed and Internet availability data, ISP representative's answers and their websites were analyzed. Internet availability data about each hometown was given by ISP representatives from Comcast, Frontier, Verizon and Citynet. ISP representatives also shared information about the highest speed Megabits per second (Mpbs) that they can provide in West Virginia. This information shows the decision residents in rural areas have to make when it comes to purchasing Internet packages. The bandwidth speed shows whether it is a wise financial decision to purchase Internet if the bandwidth speed is slow. The Internet availability in each hometown is also important to research and analyze because if Internet is available by only one ISP, then that gives the resident only one option for 
Internet service. If that is the case, then the resident may not be able to afford the only Internet option provided, which is why the prices for each hometown was also collected.

\section{Newspaper circulation}

Each $\mathrm{COH}$ artist's hometown newspaper was sent a press release containing information about the artist and the card they designed for the fundraiser. In order to support the notion that press releases are still the foundation of public relations methods not only in West Virginia, but also in rural communities throughout the United States, newspaper circulation data was collected and analyzed from the Editor \& Publisher 2012 Yearbook.

Data was collected about the following newspapers: Clarksburg ExponentTelegram, Elkins Inter-Mountain, The (Morgantown) Dominion Post, Beckley RegisterHerald and Nicholas Chronicle. The days the newspapers are published were collected, as well as the daily and weekend circulation numbers. The price of each newspaper monthly and yearly was collected. The days the newspapers are sent out show how often a resident in that hometown has the chance to see a printed press release. The circulation numbers were important to collect for this study because that data indicates how many people receive a newspaper daily and/or on the weekends. This information is interesting to compare to each hometown's population. The monthly and yearly price of each newspaper was collected so that it could be compared to the Internet package data collected when researching Internet availability and bandwidth speed.

\section{$\mathrm{COH}$ profits}

In order to compare past years $\mathrm{COH}$ fundraiser profits to the $2012 \mathrm{COH}$ fundraiser, profits from 2008-2012 were provided by Lora Edgell, director of the 
Children's Miracle Network. The Planning, Marketing and Communications department incorporated Facebook into this year's $\mathrm{COH}$ fundraiser. The Planning, Marketing and Communications News Service Director, Angela Jones-Knopf, posted about an artist and their card throughout the duration of the fundraiser (Figure 2). The profits were collected and analyzed to show whether the Facebook posts had an impact in the 2012 $\mathrm{COH}$ fundraiser.

Figure 2 - Facebook post

A.nen WVU Children's Hospital shared a link.

thtt November 9, 2012 (e)

The featured card of the day is "Home for the Holidays" by Leah Fletcher, 22, of Harrison County. You can read all about Leah and her card here:

http://wwww.wvukids.com/wwuh/Content/Media/News-

Releases/Item?id=12-224

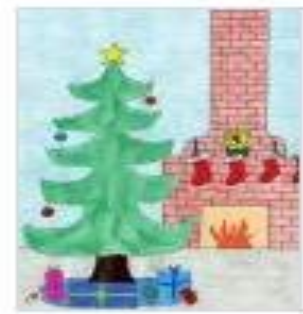

Item I wvu Kids

www.wvukids.com

11/05/2012Harrison County native's design featured in 2012 Cards of Hope collectionMORGANTOWN, W.Va. Leah Fletcher, 22, of Mt. Clare is a featured artist in the 2012 edition ofCards of Hope. The cards are the 


\section{Findings}

The purpose of this study was to support the notion that traditional public relations methods, such as press releases, still have a place in rural communities of not only West Virginia, but also in rural communities throughout the United States. In order to support that notion, through various sources data was collected, analyzed and displayed below in table and graph forms. Answers to the study's research questions and support to the hypotheses will be discussed below.

RQ1: How do demographics in the five communities chosen help determine how the residents receive their news?

The first research question examined the following of each hometown: population, persons under 5 and 18, persons 65 and older, number of households, persons per household, per capita money income, median household income and persons below poverty level. Besides the population, Mill Creek, Lost Creek and Richwood had to have data collected by the county they are in because the U.S. Census Bureau could not provide demographic information in those specific areas (Figure 3).

The population of Lost Creek, Mill Creek and Richwood are below 2,500 while Morgantown and Grafton are above 2,500. The largest age group on average in each hometown is between ages 18-65. On average, in each hometown there are two persons per household. Later on in this section, the number of households in each hometown/county will be compared to the newspaper circulation of each selected newspaper. Also, the median household income and persons below poverty level will be 
analyzed alongside the price of Internet packages and the monthly and yearly newspaper subscription prices.

Figure 3 - U.S. Census Bureau data

\begin{tabular}{|c|c|c|c|c|c|c|c|c|c|}
\hline & Population & $\begin{array}{l}\text { Persons } \\
\text { under } 5\end{array}$ & $\begin{array}{c}\text { Persons } \\
\text { under } \\
18\end{array}$ & $\begin{array}{c}\text { Persons } \\
65 \text { and } \\
\text { older }\end{array}$ & $\begin{array}{l}\text { Households } \\
2007-2011\end{array}$ & $\begin{array}{c}\begin{array}{c}\text { Persons } \\
\text { per } \\
\text { household }\end{array} \\
2007- \\
2011\end{array}$ & $\begin{array}{c}\text { Per } \\
\text { capita } \\
\text { money } \\
\text { income }\end{array}$ & $\begin{array}{c}\text { Median } \\
\text { household } \\
\text { income }\end{array}$ & $\begin{array}{c}\text { Persons } \\
\text { below } \\
\text { poverty } \\
\text { level }\end{array}$ \\
\hline Lost Creek/ & & & & & & & & & \\
\hline $\begin{array}{l}\text { Harrison } \\
\text { County }\end{array}$ & $498(\mathrm{LC})$ & $5.8 \%$ & $21.9 \%$ & $16.7 \%$ & 27,696 & 2.45 & $\$ 21,846$ & $\$ 40,556$ & $18.2 \%$ \\
\hline & & & & & & & & & \\
\hline $\begin{array}{l}\text { Randolph } \\
\text { County }\end{array}$ & 725 (MC) & $5.1 \%$ & $19.1 \%$ & $18.3 \%$ & 11,276 & 2.43 & $\$ 18,974$ & $\$ 35,560$ & $18.4 \%$ \\
\hline Grafton & 5,171 & $6.7 \%$ & $21.9 \%$ & $19.0 \%$ & 2,204 & 2.26 & $\$ 16,369$ & $\$ 27,418$ & $23.7 \%$ \\
\hline $\begin{array}{l}\text { Richwood/ } \\
\text { Nicholas }\end{array}$ & $2,054(\mathrm{R})$ & $5.7 \%$ & $20.9 \%$ & $17.5 \%$ & 10,149 & 2.57 & $\$ 20,455$ & $\$ 39,636$ & $18.6 \%$ \\
\hline County & & & & & & & & & \\
\hline Morgantown & 30,293 & $2.7 \%$ & $8.2 \%$ & $8.1 \%$ & 10,082 & 2.23 & $\$ 18,648$ & $\$ 25,948$ & $36.4 \%$ \\
\hline U.S.A & $313,914,040$ & $6.5 \%$ & $23.7 \%$ & $13.3 \%$ & $114,761,359$ & 2.60 & $\$ 27,915$ & $\$ 52,762$ & $14.3 \%$ \\
\hline
\end{tabular}

RQ2: How does geography in the five communities chosen help determine how the residents receive their news? 
The above research question analyzed Ookla's Net Index highest speed Internet ranking of each state in descending order (Figure 4). West Virginia ranks as being the $48^{\text {th }}$ highest speed Internet state. It is in the top 20 of having the slowest Internet speed.

\section{Figure 4 - United States download speed rankings}

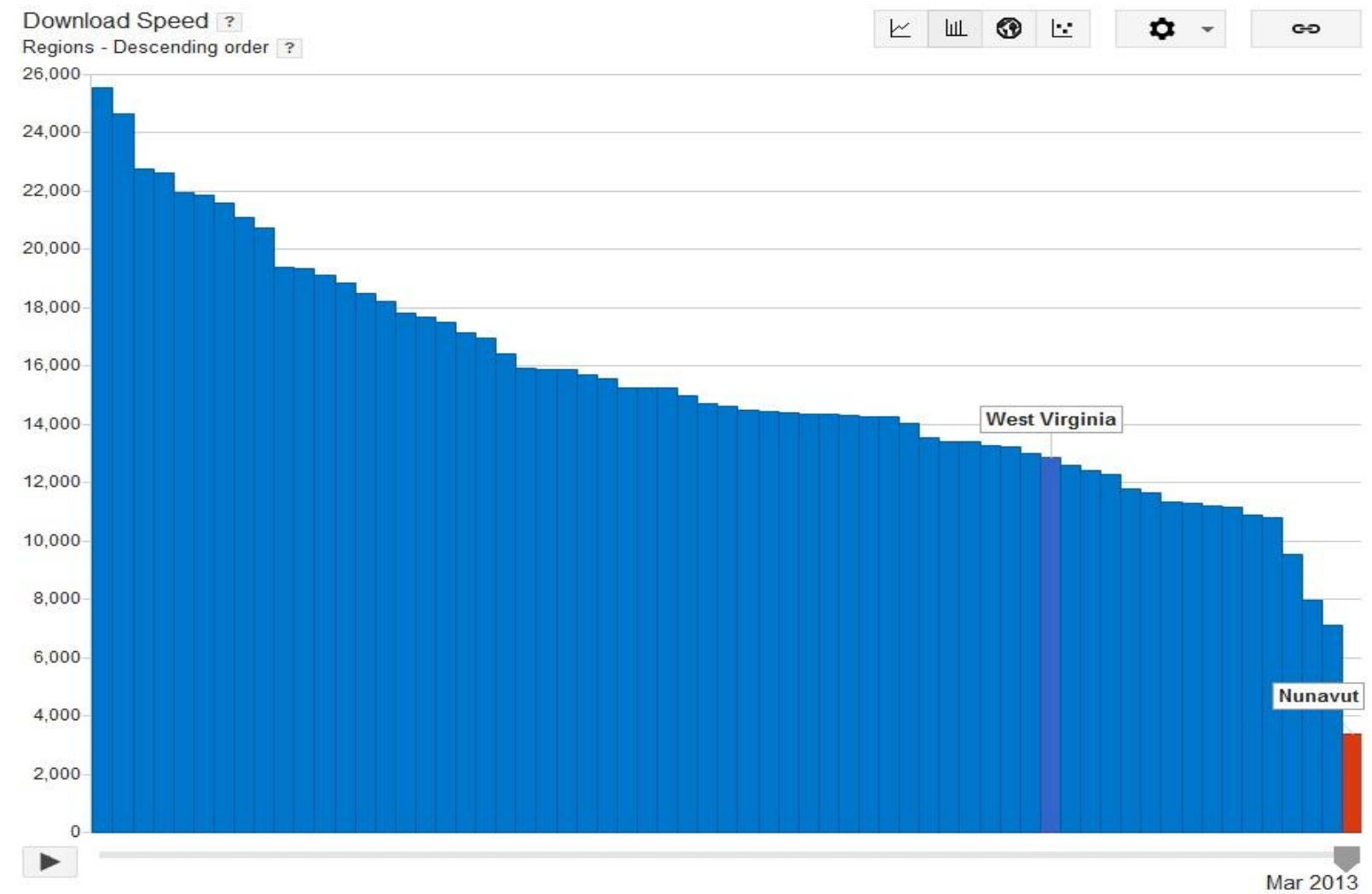

RQ3: How does the bandwidth speed in the five communities chosen help determine how the residents receive their news?

The third research question was examined by collecting the highest speed provided in West Virginia by ISPs. In Figure 5, the highest Mbps that each ISP can 
provide is shown. Also, each ISP package provides the highest Mbps it can provide to a resident's home in that area.

Figure 5: Bandwidth speed, Internet availability and package prices

\begin{tabular}{|c|c|c|c|c|}
\hline & Comcast & Frontier & Verizon & CityNet \\
\hline $\begin{array}{c}\text { West Virginia } \\
\text { Mbps }\end{array}$ & 305 & 24 & $\begin{array}{c}\text { 75/35 } \\
\text { download/upload }\end{array}$ & Dial up \\
\hline Morgantown & $\begin{array}{c}\text { Available } \\
34.99 \text { month/20 } \\
\text { Mbps }\end{array}$ & $\begin{array}{c}\text { Available } \\
39.99 \text { month/6 } \\
\text { Mbps }\end{array}$ & Not Available & $\begin{array}{l}\text { Available } \\
19.95 \text { month }\end{array}$ \\
\hline Grafton & $\begin{array}{c}\text { Available } \\
34.99 \text { month/20 } \\
\text { Mbps }\end{array}$ & $\begin{array}{c}\text { Available } \\
39.99 \text { month/6 } \\
\text { Mbps }\end{array}$ & Not Available & $\begin{array}{c}\text { Available } \\
19.95 \text { month }\end{array}$ \\
\hline Lost Creek & Not Available & $\begin{array}{c}\text { Available } \\
39.99 \text { month/6 } \\
\text { Mbps }\end{array}$ & Not Available & $\begin{array}{c}\text { Available } \\
19.95 \text { month }\end{array}$ \\
\hline Mill Creek & Not Available & $\begin{array}{c}\text { Available } \\
39.99 \text { month/6 } \\
\text { Mbps }\end{array}$ & Not Available & $\begin{array}{c}\text { Available } \\
19.95 \text { month }\end{array}$ \\
\hline Richwood & Not Available & $\begin{array}{c}\text { Available } \\
39.99 \text { month } / 6 \\
\text { Mbps }\end{array}$ & Not Available & $\begin{array}{c}\text { Available } \\
19.95 \text { month }\end{array}$ \\
\hline
\end{tabular}

RQ4: How does the lack of financial gain for ISPs help determine how the residents receive their news?

The last research question was examined by collecting the Internet availability provided by four ISPs. Figure 5 shows that the large cable and Internet providers such 
as Comcast and Verizon either offer Internet to few or none of the hometowns selected. Comcast only provides internet to the largely populated hometowns, Morgantown and Grafton. Verizon does not provide internet to any of the hometowns selected. The ISPs Frontier and Citynet provide Internet to each hometown. The Mbps that Frontier offers at the lowest price is $6 \mathrm{Mbps}$.

Comcast's package only offered in Morgantown and Grafton would cost $\$ 419.88$ a year. Frontier's package offered in all five hometowns would cost $\$ 479.88$ a year.

Citynet's dial up package offered in all five hometowns would cost $\$ 239.40$ a year.

H1: The profits raised from this year's Cards of Hope fundraiser will be greater than the profits raised from the 2011 Cards of Hope fundraiser.

In order to support this hypothesis, $\mathrm{COH}$ profits from 2008-2012 were collected (Figure 6). The data shown in Figure 6 provides support to $\mathrm{H} 1$.

Figure 6: $\mathrm{COH}$ profits, 2008-2012

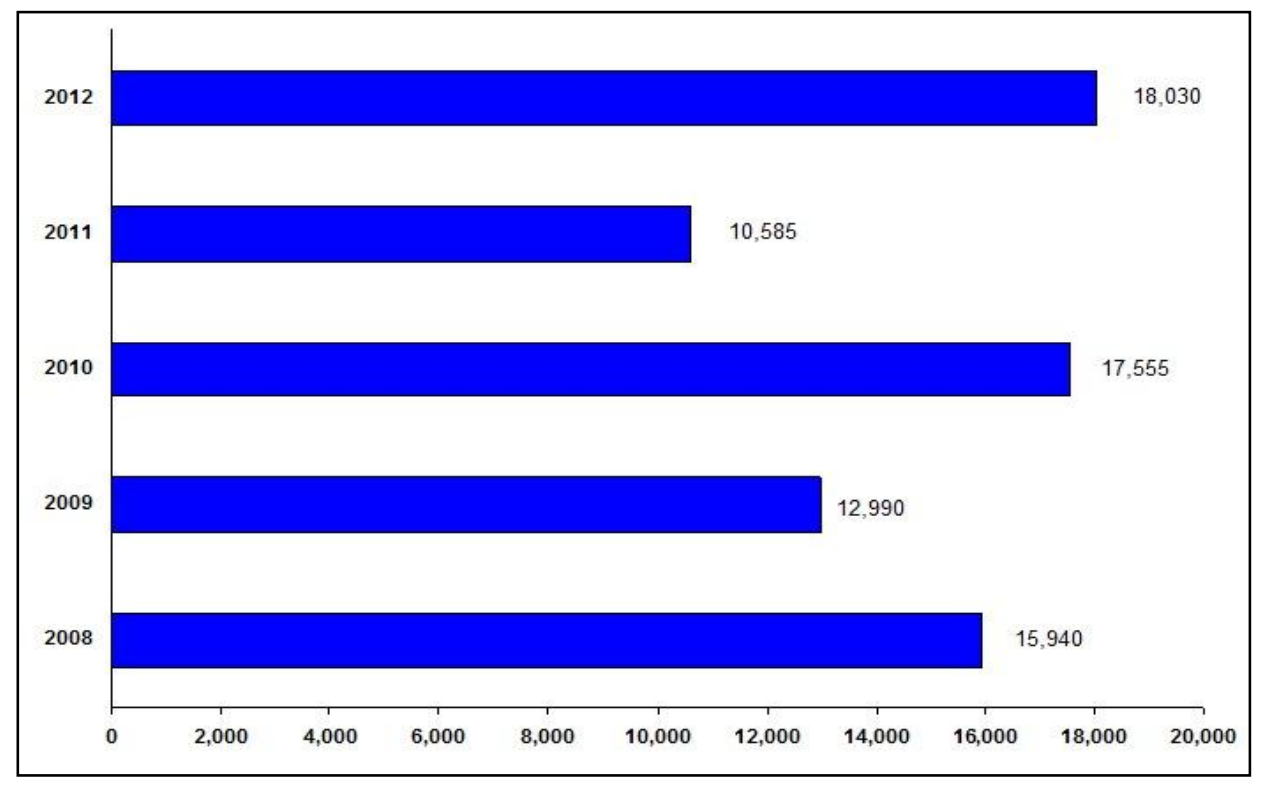


H2: Press releases are still the foundation of public relations in rural communities, specifically West Virginia.

This hypothesis is supported by the data collected by the 2012 Editor \& Publisher Yearbook (Figure 7). When comparing number of households data (collected from the U.S. Bureau), to the newspaper circulation, the numbers show that newspaper subscriptions are high in these five hometowns. High newspaper subscriptions support the hypothesis that press releases are still the foundation of public relations in rural communities, specifically West Virginia. 
Figure 7 - Newspaper circulation

\begin{tabular}{|c|c|c|c|}
\hline & Published & Circulation & Price \\
\hline $\begin{array}{l}\text { The Exponent Telegram } \\
\text { Leah Fletcher (Lost Creek) }\end{array}$ & Daily & $\begin{array}{l}\text { Daily: } 13,942 \\
\text { Saturday only: } 14,570 \\
\text { Sunday only: } 18,491\end{array}$ & $\begin{array}{l}15.35 / \text { month } \\
161.20 / \text { year }\end{array}$ \\
\hline $\begin{array}{c}\text { Elkins Inter-Mountain } \\
\text { Karus Grant Bell (Mill Creek) }\end{array}$ & Monday - Saturday & $\begin{array}{l}\text { Daily: } 8,891 \\
\text { Saturday only: } 9,905\end{array}$ & $\begin{array}{l}\text { 10.20/month } \\
\text { 99.95/year }\end{array}$ \\
\hline $\begin{array}{c}\text { Dominion Post } \\
\text { Katrina Oldland (Grafton) }\end{array}$ & Daily & $\begin{array}{l}\text { Daily: } 20,097 \\
\text { Saturday only: } 21,255 \\
\text { Sunday only: } 23,922\end{array}$ & $\begin{array}{l}\text { 18.20/month } \\
\text { 212.94/year }\end{array}$ \\
\hline $\begin{array}{l}\text { Beckley Register-Herald } \\
\text { Danielle Bartlett (Richwood) }\end{array}$ & Daily & $\begin{array}{c}\text { Daily: } 23,717 \\
\text { Saturday only: } 23,717 \\
\text { Sunday only: } 25,165\end{array}$ & $\begin{array}{l}\text { 12.50/month } \\
167.40 / \text { year }\end{array}$ \\
\hline $\begin{array}{l}\text { Nicholas Chronicle } \\
\text { Preston Batton } \\
\text { (Morgantown) }\end{array}$ & $\begin{array}{c}\text { Weekly - Published on } \\
\text { Thursday }\end{array}$ & Weekly: 9,000 & 28.50/year \\
\hline
\end{tabular}




\section{Discussion}

The purpose of this study is to support the notion that traditional public relations methods, such as press releases, still have a place in rural communities of not only West Virginia, but also in rural communities throughout the United States. Based on the study's research findings, the following observations were made.

\section{Population}

The U.S. Census Bureau defines the population of Lost Creek, Mill Creek and Richwood as rural areas, while Morgantown and Grafton are defined as Urban Clusters (UCs). UCs are defined as having a population of at least 2,500 but less than 50,000.

\section{Internet availability \& bandwidth speed}

After analyzing collected data, there is a strong relationship between Ookla's Net Index download speed rankings and the Mbps information that was provided by the ISPs. Overall, Internet availability is not strong in West Virginia. West Virginia is ranked as the $16^{\text {th }}$ state with the lowest download speed as of March 2013. The Mbps that ISPs provide residents in the five hometowns are also slow. The more populated areas such as Morgantown and Grafton are provided with more Mbps then the other three hometowns. Also, Morgantown and Grafton are the only two hometowns out of the five to which Comcast provides Internet service. The ISP Frontier provides Internet to all five hometowns but the average package is only give $6 \mathrm{Mbps}$. The low amount of Mbps brings up the question of whether an Internet package is worth purchasing. This information may cause rural residents to choose another form to receive their news. Rural residents are not provided with a high amount of Mbps, therefore limiting the chance of social media use. 
The Internet availability in West Virginia is scarce. Big ISPs such as Comcast and Verizon provide either little or nonexistent Internet to these areas. When Internet availability and bandwidth speed data was collected, Verizon showed that it does not provide Internet to any of the hometowns selected. It is inferred that large ISPs like Comcast and Verizon feel that providing Internet to these areas is not worth the money and resources it would take to make Internet more available in these areas.

This is something that might never change. Internet availability in rural areas is low. There are 15 states under West Virginia that have an even lower download speed. Based on the research it is appropriate to infer that rural states have low download speeds; therefore, the use of social media forms in these states is lower than those living in urban states. This conclusion supports the notion that press releases and other forms of traditional public relations methods are the foundation in rural areas.

\section{Poverty levels \& household income}

When comparing the poverty level percentages and household incomes of the five West Virginia hometowns to the United States' average poverty level percentages and household incomes, it can be concluded that West Virginia has lower household incomes and higher poverty level percentages than those of the United States. This information infers that residents living in rural areas in West Virginia may not have the financial ability to purchase Internet packages. The household income of those in West Virginia is noticeably lower than the average of the United States household income. If one is living in poverty, they are more than likely not going to be able to afford the Internet. It is evident that the use of social media may be lower in more rural areas 
because of the household's income and financial ability or lack thereof to purchase an Internet package.

\section{Newspaper subscriptions vs. Internet packages}

There is a gap between the newspaper subscriptions and the Internet packages of those in the five hometowns. The data shows the ISP Frontier's lowest Internet package starting at $\$ 39.99$ per month while each hometown newspapers subscription is drastically lower than the Internet package. This data suggests that purchasing a newspaper subscription is more likely in rural areas because of low household incomes, download speed and Internet availability.

\section{$\mathrm{COH}$ profits}

Figure 6 shows that the profits raised from the $2012 \mathrm{COH}$ fundraiser are greater than the profits raised from the 2011 fundraiser. The 2012 fundraiser incorporated the use of Facebook, as well as press releases to promote the artist's cards. Morgantown and Grafton are highly populated, have higher amounts of Mbps and more available Internet coverage. Residents living in these UCs are more likely to see the posts than those living in the rural areas. It is possible to suggest that the increase in profits is because of the promotion through Facebook. Although, if the profits made during the 2010 fundraiser are compared to those made during the 2012 fundraiser there is a slight increase from the 2010 profits to the 2012 profits. This information suggests that the use of other public relations methods such as word-of-mouth or press releases led to the increase in profits.

Overall, as mentioned in the literature review, Kent \& Taylor (2010) said that new technological forms and channels, such as electronic pitching, Podcasting, and blogging 
prevail over traditional news releases and media kits. This study contradicts that statement. In some cases, social media may be the best public relations tool to use in promoting a fundraiser. When targeting rural areas, this study's supports the notion that traditional public relations methods such as press releases is the best tool to use in promoting a fundraiser. Taking into account the targeted audiences' Internet availability and location are areas that should be researched before choosing a public relations method.

This study suggests that the promotion of a fundraiser in a rural area has a higher chance of success through traditional public relations methods such as press releases and word of mouth communication than through forms of social media. As mentioned earlier in the literature review, Melanthiou and Papasolomou (2012) said that marketing public relations has the ability to work effectively with traditional promotional methods to help generate an immediate response, create long-term relationships and spread word of mouth. This is true when promoting a fundraiser in rural areas. The high newspaper subscription numbers that were collected during this study suggest that rural residents are likely to see a press release printed in the newspaper and spread that information throughout the area. In rural areas, word of mouth communication and press releases may be the only way news is spread. This is an important factor to remember when the promotion plan is being discussed.

This study suggests through the data collected that researching the targeted audience demographic, geography, Internet availability and bandwidth speed is key when promoting a fundraiser. In rural areas, the variables that were researched in this study are important to research in all fundraisers being conducted in rural areas. Curtis 
et al. (2010) noted that social media techniques will become more abundant as public relations practitioners become mindful of their effectiveness in regards to reaching their targeted audiences, promoting a specific cause, and further developing communication strategies. This study's findings contradicts that statement and reinforces the notion that while social media is best promotional method in some areas, a targeted audience living in a rural areas needs to be reached differently. This study's findings suggest that because of low household income, poverty levels and low Internet availability a different public relations method needs to be used. This supports the notion that in rural areas, press releases are still the foundation of public relations.

In recommendation, the author would advise public relations practitioners targeting an audience that resides in a rural area to research the following variables before choosing a public relations promotion method. States that are rural and have low amounts of Mbps and Internet availability, it is important to utilize traditional public relations methods during the promotion process. 


\section{Limitations}

Due to the graduate deadlines, this study examined only five rural areas out of the many that exist in West Virginia, the findings should not be generalizable to all West Virginia areas. Because of these limitations, the researcher was unable to examine all of the rural areas of West Virginia. Therefore, more intensive data and findings can be researched and analyzed. The time constraint also limited the researcher from collecting specific U.S. Census Bureau information on the three rural hometowns: Mill Creek, Lost Creek and Richwood. The U.S. Census Bureau could only provide the researcher with data from the counties these hometowns reside in. Therefore, specific data on the rural hometowns was unable to be collected.

The data collected from the ISP representatives was also limited. The researcher had hoped to collect data on approximately how many people were provided Internet by each ISP. That information was not attainable due to privacy issues. Therefore, precise information regarding Internet availability to the study was not discovered.

The graduate deadlines limited the researcher from conducting more qualitative research in the five rural areas. Conducting rural resident interviews may have provided this study with more in depth findings on the use of social media. 


\section{Further Research}

Extensive research could be conducted in rural areas throughout the United States. Collecting the same data that was collected in this study and comparing it to those of other rural states could be interesting and create new claims on this topic.

It also would be interesting to compare the rural states to urban states. Collecting data from each and drawing conclusions from the data may lead to a better understanding of why certain public relations methods are better suited for different areas.

Because interviewing the rural residents in the five hometowns could not be accomplished because of graduate deadlines, it would be interesting to conduct this form of qualitative research. The responses from residents may create a more in depth study. Researching whether Internet is used in the household or if it is, which media outlet is preferred when receiving news would be interesting to research. 


\section{Conclusion}

After conducting this case study, it is clear that certain public relations methods are better than others when reaching rural areas. Press releases are still the foundation of public relations and rural areas. This claim that is supported by this study's data, provides explanation to the importance of knowing the targeted audience. This study reinforces the claim that a successful fundraiser can be accomplished by researching the targeted audience. Public relations practitioners that are creating public relations plans throughout the United States need to establish the best way to reach their audience. If the fundraiser will be promoted in rural areas, referring to this study's findings may be useful.

Today, public relations practitioners promote the use of social media in fundraisers and campaigns. Literature has suggested that traditional public relations methods are dead. This study's findings suggest otherwise. Traditional public relations may not be the first method that comes to the mind of public relations practitioners promoting to audiences in urban areas, but it should come to mind of those promoting in rural areas. Internet is not easily attained everywhere in the United States. This claim has been forgotten in the public relations realm. The advances social media has made in the past few years has made its way into being a key tool in public relations methods, and in turn, covered up the need some still have for traditional public relations methods.

Overall, this study supports the notion that not only is traditional public relations not dead, but it is also necessary when promoting in certain areas. Press releases are still the foundation of public relations in rural areas. When public relation practitioners 
are creating a plan for either a campaign, fundraiser or to raise awareness, this study can suggest what to research to produce a successfully promoted fundraiser. 


\section{References}

Adoption and use of social media among public health departments. (2012). BMC Public Health, 12(1), 242-247.

Argan, M. (2012). Word-of-Mouth (WOM) as A Tool of Health Communication: A Case Study of Turkey. Healthmed, 6(1), 216-221.

Bridgen, L. (2011). Emotional labour and the pursuit of the personal brand: Public relations practitioners' use of social media. Journal Of Media Practice, 12(1), 6176.

Bulldog Reporter. (2011, May 16). Do You Target a Local Audience? Then You Better Get Hip To the Latest Mobile Marketing Strategies: According To a New Pew Survey, Half of U.S. Adults Get Their Local News From Mobile Devices. Retrieved from http://www.bulldogreporter.com/dailydog/article/do-you-targetlocal-audience-then-you-better-get-hip-latest-mobile-marketing-strate

Cain, J. (2011). Social media in health care: The case for organizational policy and employee education. American Journal Of Health-System Pharmacy, 68(11), 1036-1040.

Curtis, L., Edwards, C., Fraser, K. L., Gudelsky, S., Holmquist, J., Thornton, K., \& Sweetser, K. D. (2010). Adoption of social media for public relations by nonprofit organizations. Public Relations Review, 36(1), 90-92.

Fathi, S. (2012, June 9). Traditional PR Is Still In Style : Four Timeless Media Relations Tools. Retrieved from http://www.bulldogreporter.com/dailydog/article/traditionalpr-still-style-four-timeless-media-relations-tools

Kent, M. L. \& Taylor, M. (2010). Anticipatory socialization in the use of social media in public relations: A content analysis of PRSA's Public Relations Tactics. Public Relations Review, 36(3), 207-214.

Khang, H., Ki, E., \& Ye, L. (2012). Social Media Research in Advertising, Communication, Marketing, and Public Relations, 1997-2010. Journalism \& Mass Communication Quarterly, 89(2), 279-298.

G. Miller. (2012, May 17). Whatever Happened To Traditional PR? Retrieved from http://www.bulldogreporter.com/dailydog/article/whatever-happened-traditional-pr

Melanthiou, Y., \& Papasolomou, I. (2012). Social Media: Marketing Public Relations' New Best Friend. Journal Of Promotion Management, 18(3), 319-328.

Neiger, B. L., Thackeray, R., \& Keller, H. (2012). Integrating Social Media and Social Marketing: A Four-Step Process. Health Promotion Practice, 13(2), 165-168. 
Scott, D., (2007). The New Rules of Marketing and PR. 1st ed. Hoboken, New Jersey: John Wiley \& Sons, Inc.

Severin, W., Tankard Jr., J. (2001). Communication Theories. $5^{\text {th }}$ ed. United States: Addison Wesley Longman, Inc.

Sheehan, M., Xavier, R., (2009). Public Relations Campaigns. 1st ed. New York: Oxford University Press.

Solis, B., Breakenridge, D., (2009). Putting the Public Back in Public Relations. 1st ed. New Jersey: FT Press.

Swanborn, P. (2010). Case Study Research. Thousand Oaks, CA: Sage Publications.

Ullah, S., Ahmad, A., \& Khan, T. (2012). Fundraising for Sustainable Community Development and Role of Social Media: Case of Pakistan. International Journal Of Business, Humanities \& Technology, 2(3), 73-79.

Watson, T. (2012). The evolution of public relations measurement and evaluation. Public Relations Review, 38(3), 390-398.

Yin, R. K. (1993). Applications of Case Study Research. Newbury Park, CA: Sage Publications.

Yin, R. K. (2003). Case study research: Design and methods (3rd ed.). Thousand Oaks, CA: Sage Publications. 